infatuated host who seem to be wholly actuated by motives of selfinterest, or warped by the narrowed spirit of opposition, rendering nugatory the laudable and energetic endeavours of those really entertaining unsophisticated feelings for the welfare of that high and honourable profession to which they belong.

Apologizing for the length to which the foregoing remarks have imperceptibly extended, it may be added that the writer of this letter will be delighted if it should have the good fortune to attract the attention of other of your readers to the subject. By true and authentic accounts of those evils which act in opposition to general good, by communications from the various localities in the three kingdoms, by fair and unprejudiced statements 1 rom parties cognizant of the existence of any practices or systems detrimental to the welfare of the profession at large,- by such, and publicity being given to the same, can we only hope for correct deductions to be drawn, and a positive knowledge of what is inimical or otherwise, for the guidance of those concerned in the concoction of legal enactments. It is, then, an incumbent duty imposed upon all, to make any injurious systems to be generally known, and especially to communicate them to those quarters where efforts are made to produce something like reformation in the profession. Let, then, societies be formed, the members act in unison, and not suffer their rights and privileges to be marred and usurped by an extorting and illiberal public.

I am, Sir, your obedient, humble servant,

Pickering, Yorkshire, July 29th, 1815 .

OMEGA.

\section{ASSOCIATED FELLOWS AND MEMBERS OF THE ROYAL COLLEGE OF SURGEONS OF ENGLAND. To the Editor of THE LANCET.}

Sin,-Several letters have" been addressed to me from the country, inquiring whether it is desirable that gentlemen who have signed the requisition to Mr. Guthrie should attach their names to the memorial to Sir James Graham, originating in Bristol. Allow me, through your columns, to say, that I can see no objection to any of our friends signing that memorial, so long as they will not consider that in so doing they accomplish all that is riecessary to be done by them in the matter.

A memorial was lately forwarded to the Home Secretary, signed by the chairman and honorary secretaries of the London Committee, in behalf of the twelve hundred and seventy fellows and members of the College of Surgeons who have signed the requisition to Mr. Guthrie, urging Sir James not to grant any supplementary charter to the Council of the College without the members being first made acquainted with its principal provisions, and having time allowed to express their opinions respecting them.

The Bristol memorial goes a step further, and asks that " all those who were admitted members of the Royal College of Surgeons of England, previous to September, 1843, (under such restrictions as her Majesty's Government may consider necessary,) shall, upon just and equitable principles, be placed upon an equality with recently elected fellows.

Now, Sir, this request is a perfectly fair one, but I think that Sir James Graham, after the experience he has had, will expect us to say what we consider "just and equitable principles," and what the "necessary restrictions."

The members of the Council tell us that Sir James Graham was made acquainted with, and approved, the appointment of fellows made under the new Charter-in other words, considered it to be "just and equitable;" but the great body of members seem to be of an entirely different opinion. The Home Secretary may, therefore, fairly enough expect them to say what mode of appointing the fellows they consider to be desirable, and what are the restrictions to which they would be prepared to consent. These are not, perhaps, very easy questions to solve, but these, and others, must be solved, and solved by the fellows and members themselves, or they will, in all probability, have a supple. mentary charter given which will afford almost as small an amount of satisfaction as the former.

I trust our friends in Bristol will understand that these remarks are made from no wish to oppose their proceeding, which is quite in accordance with the steps we have alrealy taken; but I must be allowed to express the hope that they will still be prepared, so soon as the Medical Bill is printed, to join us in considering its provisions, and also in suggesting such alterations in this and in the late Charter as may render them acceptable to the great majority of the profession.

Allow me to add, that a sub-committee is engaged in preparing a series of questions respecting the provisions of the Bill and Charter, which will be completed as soon as the Bill is printed. These questions, accompanied with such suggestions as it may seem desirable to the committee in London to make, will be for- warded to each of the committees in the country, with a request that they may be submitted to the members of the profession resident in their district, at a meeting called for that purpose. In this way we shall hope to obtain such a general expression of opinion on the part of the profession throughout the country as to the leading points of these measures, as may afford a satisfactory basis for future medical legislation.

I remain, Sir, your obedient servant,

D. Otthey, Hon. Sec.

Committee Room, Freemasons' Tavern, August 4th, 1845.

\section{THE SUPPLEMENTARY CHARTER OF THE COLLEGE OF SURGEONS.}

To the Editor of THE Lancet.

SrR,-As there at present appears some probability of Sir James Graham advising the Crown to grant a supplementary charter to the College of Surgeons, I cannot refrain from intimating to you, who have ever boldly come forward to the rescue of the injured, or sought to shelter the oppressed from the uplifted arm of stern injustice, the imperative necessity of urging that the principles on which it should be based, in order to satisfy the vast number of anxious expectants, should be of a liberal and enlightened character. I would therefore respectfully state, in behalf of all those gentlemen who have been admitted members subsequently to September, 1843, (or at all events within twelvemonths from the date of the late charter, that they should have the same privilege conceded to them, of being hereafter advanced to the fellowship without additional examination, or, in other words, on the same conditions as those who were admitted members antecedent to the period to which I have alluded. After mature deliberation, I am decidedly of opinion that unless these matters are diligently attended to, so far from our having to look forward to the pleasing advent of professional harmony and peace, we shall be only contributing to protract the confusion and discord which are unhappily but too prevalent, and assisting to continue a most unpleasant and profitless discussion respecting legislative enactments and royal charters of incorporation, in which, perhaps, as I have elsewhere observed, there may be much that is chimerical and visionary, instead of zealously exerting our best energies for the more worthy purpose of concluding existing animosities, and replacing them by those serene and calmer feelings which are so much more congenial to our successful advancement in the medical sciences. Sincerely hoping that these disinterested remarks may accomplish their object by taking effect in the proper quarter.

I remain, Sir, your obedient servant,

Cheltenham, August 4th, 1845 .

A Fellow of the College.

\section{HOUSE OF COMMONS.}

Tuesday, August 5th, 1845.

Mr. WAKLEY stated that he was desirous of reminding the Right Hon. the Home Secretary that the Medicax Brlt had gone through a Committee pro form $\hat{\alpha}$ so long ago as Monday, the 28th of July, and that up to that period the altered measure had not been delivered. He was anxious to learn whether the new Bill would be in the possession of members before the Parliament was prorogued?

Sir JAMES GR AHAM replied that the amended Bill had been in the hands of the printer for some time, and that he expected it would be delivered in a few days.

\section{NEWS OF THE WEEK, REMARKS, AND CRITICISMS.}

Westminster Hospital - Professional ExiQUETTE. - The Westminster Hospital has again been the scene of some contention, in consequence of the following proceedings : Mr. Benjamin Philips wishing to leave town for a short time, procured permission of the House Committee for Mr. Brooke, a hanger-on of the hospital, to do his duty as assistant-surgeon, so far as related to the out-patients, Mr. Thompson undertaking to attend to those admitted into the house. No sooner, however, did the locum tenens obtain a footing into the hospital, than he selected a woman from among the out-patients, who was suffering from vesico-vaginal fistula, in order to try a scheme which he had long meditated, of uniting the edges of the fissure by means 
of what he calls the "bead suture." The woman was accordingly operated on, on Tuesday week last, by Mr. Brooke, without the knowledge of the authorized surgeon of the institution; and to render the proceeding still more irregular, the case was printed it a medical journal, under the heading of "Hospital Report." This "report" inferred that the operation had been successful, and eulogized the skill and dexterity of the operator.

On Tuesday last, the subject was brought before the House Committee, and the conduct of Mr. Brooke freely canvassed, the only person speaking in his favour being Mr. LYNN, one of the surgeons of the hospital, who acknowledged that he had given his sanction to the operation, after it had been performed;-not that he had seen the patient previously, for he was too busy in his "farm" at Kingston, for that!

After considerable discussion, in which the proceeding of $\mathrm{Mr}$. Brooke was condemned, and Mr. Guthrie declared that the operaation had failed, the Rev. Mr. Borradaile moved, and Mr. Furnivall seconded, the following resolution, which was carried unanimously -

"That Mr. Brooke be requested to attend to the duties assigned to $\mathrm{him}$, by the resolution of this committee of the $15 \mathrm{th}$ inst., and that his attention be directed to the laws of the institution, in reference to the performance of operations."*

The city of Paris has now fourteen hospitals and eleven asylums. The hospitals may be divided either into those which are for general diseases, acute or chronic, or into those which are for special diseases. 'The first are seven in number, and contain 3047 beds : the Hôtel Dieu, 900 beds; the Pitié, 600; the Charite, 426 ; St. Antoine, 278; Necker, 329; Cochin, 114; Beaujon, 400. Six hospitals are for special diseases, and they contain 2458 beds : St. Louis (for diseases of the skin), 800 beds; Hôpital du Midi (for syphilitic diseases in men), 200 ; Lourcin (for syphilitic diseases in women), 300; Enfants Malades, 500; Accouchements, 420; Clinique, 138. 'To these must be added the Maison Royale de Santé, for sick persons who pay, with 175 beds. The number of the beds in those fourteen hospitals amounts thus to 5680 . The eleven asylums (hospices) are divided either into hospices, strictly speaking, or into retraites (retiring-places for old persons), or finally into foundations. The first are Bicètre (for old men), with 3000 beds; Salpetrière (for old women), 5000; Incurables Hommes (for men incurably diseased), 500; Incurables Femmes (for women incurably diseased), 560; Enfants Trouvés et Orphelins (foundling and Orphan Hospital, 502. The retiring places are-Les Menages, with 702 beds; la Rochefoucauld, 213; and St. Pêrine, 182. The foundations are : - Hospices Boulard, with 12 beds; Brèzin, 300; Villars, 30. The beds of these hospices amount thus to 11,001 ; the city of Paris provides, therefore, for the relief of its sick and old pauper population, 16,681 beds. Not less than 100,000 patients and poor inhabitants of Paris enter every year these establishments, and amongst them 8000 or 9000 die there annually. The Hôtel Dieu receives annually about 16,000 patients; the Pitié, 12,000; the Charité, 7000; St. Louis, 9000, \&c. The Foundling Hospital receives annually 6000 or 7000 children. The medical department consists of 88 physicians, 38 surgeons, and not less than 2700 nurses.

'The New Apothecaries' Hall.-Mr. Terry, of Northampton, one of the honorary local secretaries of the National Association, has published a letter in the Medical Provincial Journal, which contains the following paragraph respecting the proposed College:-

"In conclusion, I would just allude to the proposed new College of General Practitioners in Medicine, Surgery, and Midwifery. The promoters of it, I have no doubt, think it will do good, but I see many sober-minded, sound judging men expressing a contrary opinion; and I still think that the first impression which the project produced upon the mind of Sir James Graham is worthy of great consideration. He said very decidedly, in bis place in parliament, that he thought it a measure tending to evil-a measure tending to lower rather than improve the interest and respectability of the general practitioner; as such, he earnestly advised the projectors of the measure to reconsider their request $\mathbf{I}$ am not aware that, in subsequently yielding to the request, Sir James Graham ever expressed any alteration of, or departure from, that opinion."

Publicity to a New Charter before granting IT.-The following resolution was unanimously adopted, at a meeting of the Manchester Medical Reform Committee, on the 24th instant:-

"That this committee, having understood that some alteration

* By the laws of the hospital, only the surgeons of the institution are allowed to perform operations in it. in the Charter of the Royal College of Surgeons of England is contemplated, most earnestly entreat Sir James Graham not to recommend her Majesty to grant any supplemental Charter to the said College, until the provisions of such supplemental Charter have been published for the information of the members of the College."

$\left.\begin{array}{l}\text { Thomas Dorrington, } \\ \text { Isaac A. Franklin, }\end{array}\right\}$ Hon. Secs.

Manchester Medical Library, July $28,1845$.

Srr,-There could be no doubt, I think, but that the Fellows of the College of Surgeons should have heen acquainted with the opinions on medical reform of all those persons whom it was proposed that they should elect members of Council on the 30 th of July. In the list of eligible Fellows, I saw the name of one who has on many occasions expressed himself very fully on the subject-namely, James Wardrop, who forcibly promulgated enlightened and liberal views on medical reform, at the meetings at the Freemasons' Hall, at which Lawrence presided; and in the evidence he gave before the Parliamentary Committee, his opinions contrasted most strongly with those of his former colleague. Yet the renegade is holding high honours in the college which he attacked, while the consistent reformer is " passed over" by the Council.-Justima.

\section{THE MEDICAL SERVICE OF THE ARMY, NAVY, AND EAST INDIA COMPANY.}

A U G U S T.

Armp.

War-Office, April.-1st West India Regiment: R. B. Wigstrom, Gent., to be assistant surgeon, vice Machardy, deceased.-Hospital Staff: Assist. surg. R. J. O'Flaherty, from 83rd Foot, to be staff surg. of the second class, vice A. Smith, M.D., deceased.

vice A. Smith, M.D., deceased.
Moy 30.-1st Foot : Assist. staff surg. J. Mee to be assist. surg., vice Moy 30.-1st Foot : Assist. staff surg. J. Mee to be assist. surg., vice
Matthew, app. to the staff.-46th: Assist. surg. W. L. Langley, M.D., from Matthew, app. to the staff.-46th: Assist. surg. W. L. Langley, M.D., from
74 th Foot, to be assist. surg., vice M'Bean, promoted in 73 ard Foot. 73 rd :

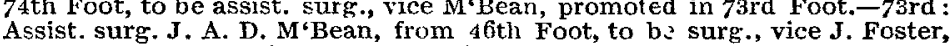
Assist. surg. J. A. D. M'Bean, from 46 th Foot, to b. surg., vice J. Foster,
M.D., who ret. upon h.p.-81 st : Assist. surg. G. Taylor, from 93rd Foot, to M.D., who ret. upon h.p. -81 st : Assist. surg. G. Taylor, from 93rd Foot, to
be surg., vice C. Dealey, who ret. upon h.p.--93rd: Assist. staff surg. W. G. be surg., vice C. Dealey, who ret. upon h.p.-93rd: Assist. staff surg. W. G. Swan, M.D., to be assist. surg., vice Taylor, prom. in the 81st Foot.- Hos
pital Staff : Dep. Inspector Gencral of Hospitals, J. Davy, M.D., from h.p., pital Staff : Dep. Inspect or Gencral of Hospitals, J. Davy, M.D., from h.p., to be Inspector General of Hospitals in the Windward and Leeward Islands
only, vice A. H. Bone, M.D., who retires upon h.p.; Assist. staff surg. T. Alexander, to be staff surg. of the second class, vice $M^{\prime} B$ ride, dec. ; Assist surg. J. A. Bostock, M.D., from 3rd Foot, to be assist. surg. to the Forces, vice Alexander, prom.; Assist. Surg. T. P. Matthew, from 1st Foot, to be to be assist. surg. to the Forces, vice Swan, app. to the 93 rd Foot.

be assist. surg. to the Forces, vice swan, app. to the gard Foot. June 6.-54th Foot : G. M`Cullock, M.D., to be assist. surg., vice Docker, app. to 60th Foot.-60th: Assist. surg. E. S. Docker, from 54th Foot, to be assist. surg, vice D. Morice, who ret. upon h.p.-63rd: Assist. surg. R. Lewins, M.D., to be assist. surg., vice Stuart, who exch.-83rd : J. Flyter Staff : Assist. surg. W. Stuart, M.D., from 63rd Foot, to be assist. surg. to Staff: Assist. surg. W. Stuart, M.D., from
the Forces, vice Lewins, who exchanges.

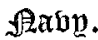
PROMOTIONS.

Surgeons-J. Stirling, and J. P. Burke. APPOINTMENTS.

Surgeons-H. Baker (1840), in charge of the convict ship Stratheden; C. K. Nutt (1840), in charge of the convict ship Lloyds; J. Syme (1834), to Crocodile; J. Rees (1842), of Frolic, to Curacoa; R. D. Pritchard (1841), to alliope, 26.

Assistant Surgeons-J. Campbell, M.D. (1836), to Actæon, vice G M'Clure, promoted; W. Bule (1841), to Cuckoo; W. Walsh (1839), from Melville Hos pital, to Penguin packet brig; M. Burt 1 n, M.D. (1841), to Crocodile.-Act-
ing additional : C. D. Shephard (1845), to Vernon, for service at Brazils ; D. J. Dujgan (1844), of Victory, to Vernon flag-ship, for service in the Brazils; F. F. Morgan and J. Plilip, to Victory, for service at Haslar Hospi al; W' Ross, M.D. (1806), and W. H. Cameron, to Caledonia, for service at Plymouth Hospital ; F. M'Aree (1845), from Victory, C. Roberts (1845), ard A. Brown, Hospital ; F. M Aree (1845), from Victory, C. Roberts (1845), ard A. Brown, to Penguin; D. Synie (act. addit.), to Hibernia; C. Douglas (act. addit.), to Vernon.

At Ascensiom, DEATHs. At Ascension, Surg. Patrick Brenan (1811), of Hydra, steam sloop.-
June 19th, Surg. George Walker (1804).

IEast Fntria (Tompanp.

(Overland Mails of July 22 nd and Aug. 2nd.) BOMBAY.

Asststant Surgeons Admited to The Service.-Messrs. M. Johnston, F. Turnbull, M.D., H. S. Garner, J. N. Tressider, R. D. D. Allan, M.D. R. W. Macauley, M.D.-Vet. Surg. : W. W. Barth, directed to join the 9 th light cavalry at Cawnpore.

The undermentioned medical officers have been pronounced by committee, to have acquired that colloquial proficiency in the vernacular language of the men, which is contemplated by general orders of the 20th April, $1844:-$ Assist. surg. G. Lacon, M.D., 9th N.I. ; Assist. surgs. J. Macrae, M.D., and J. B. Harrison, M.D., medical department.

PROMOTIONS.

Assist. surg. W. Trail, M.D., of the Madras establishment, to be civil assistant surg. at Malacca.-Assist. surg. M. A. B. Gerrard, to be civi assist. surg. of Furruckabad.-Assist. surg. K. M. Scott, leave for six months on priv. aff.--Surg. H. Sill posted to sth N.I.-Assist. surg. J. F. 